\title{
Ecology, breeding biology and breeding season displacement of the shelduck (Tadorna tadorna) on walfisch island/wismar bay, Germany
}

\begin{abstract}
Shelduck (Tadorna tadorna) breeding biological data for Walfisch Island/Wismar Bay, Germany, were recorded for the years 1971 and 2005. Some $64 \%$ of the breeding sites were in artificial nest holes, $15 \%$ of the birds were free breeders, $14 \%$ brooded under wooden huts or piles of planks and $7 \%$ brooded in holes partly excavated by the birds themselves or in Red Fox (Vulpes vulpes) dens. The average clutch size was 11.11 eggs. A single case was recorded of a mixed clutch with a Red-breasted Merganser (Mergus serrator).
\end{abstract}

Shelduck ring recoveries to date indicate - in part - long-term breeding site fidelity. Ring recoveries from Shelducks ringed as chicks demonstrate settlement behavior in the vicinity of the birthplace.

A comparison of captured breeding site seeking and female breeding site visiting birds in the period 1971 to 1988 , with those captured in the period 1989 to 2005, show a forward displacement of the breeding season by 19.16 days (1.28 days per year).

Keywords: Shelduck (Tadorna tadorna), breeding grounds, settlement behavior, breeding season, forward displacement, recoveries, climate change, baltic sea
Volume I Issue I - 2016

Rolf Nessing

Clara-Zetkin-Strasse, Germany

Correspondence: Rolf Nessing, Clara-Zetkin-Strasse 16, D-17279 Lychen, Germany, Email RONES@t-online.de

Received: October 01, 2015 | Published: March 03, 2016

\section{Introduction}

In Germany, the Shelduck (Tadorna tadorna) breeds above all along the North Sea and Baltic coasts and principally in the Federal States of Lower Saxony and Schleswig-Holstein (Figure 1). In the Federal State of Mecklenburg-Western Pomerania the Shelduck breeds in the coastal bays of the Baltic and the waters of the salt marshes, occasionally also on the main Baltic coastline. Since about the 1970s it also nests regularly on the Rivers Elbe, Oder, and sporadically on a number of inland lakes of the coastal hinterland. Up until, and into the 1970s, more than 200 pairs bred in Mecklenburg-Western Pomerania, ${ }^{1}$ and in the 1980 s some 250 pairs. ${ }^{1}$ Of this number, some 20 to 30 pairs breed in the whole of Wismar Bay and the adjacent salt lagoon. ${ }^{2,3}$ These 20 to 30 breeding pairs, almost all from Wismar Bay, were mentioned earlier by. ${ }^{4}$ Eichstädt et al. ${ }^{5}$ estimated a complete population of only 150 to a maximum of 200 breeding pairs for Mecklenburg-Western Pomerania.

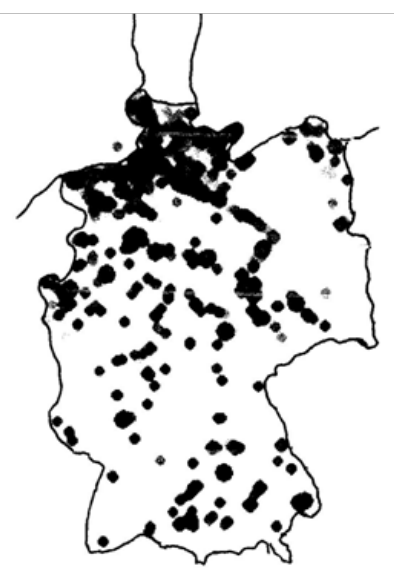

Figure I Shelduck sightings in Germany between 01.05 and 22.07.20I4.
Almost the half of the Shelducks appears to breed in protected areas. ${ }^{2}$ According to Köppen, ${ }^{6} 94$ BP bred in 13 protected areas in Mecklenburg-Western Pomerania in 1989, in 1992>85 BP and 1995 58-60 BP. Köppen ${ }^{6}$ predicted both a short term and long term breeding population decline for the coast of Mecklenburg-Western Pomerania. In 2001, a total of 107 breeding pairs were recorded in 21 of 31 coastal bird reserves. ${ }^{7}$ According to Flade, ${ }^{8}$ the Shelduck is one of the indicator species for the sea coast in Mecklenburg-Western Pomerania, especially in the dunes and the Baltic salt meadows.

\section{Materials and methods}

\section{Study area}

Walfisch Island $\left(53^{\circ} 56^{\prime} \mathrm{N}, 11^{\circ} 26^{\prime} \mathrm{E}\right)$, a designated nature reserve since 1990, is an island some 12 ha in size located in the inner Wismar Bay, belonging to the Hanseatic City of Wismar in the Federal State of Mecklenburg-Western Pomerania. The Insel Walfisch ${ }^{9}$ nature reserve is part of the EU bird reserve 'Coastal Landscape of Wismar Bay'.

Between 1952 and 1956, dredged material from the neighboring navigation channel and the port of Wismar was deposited on the originally small Pleistocene boulder clay core, creating an almost quadrangular sand bar. The island has now once again taken on a more stretched form, with an extension in an almost north-south direction and erosion of the angular land projections in the northeast and southeast of the island left over from the original dredging deposits.

The vegetation of the former deposited areas is dominated by Wood Small-reed (Calamagrostis epigejo). The characteristic botanical species of the island recorded over the last 30 years include Poison Hemlock (Conium maculatum), Black Henbane (Hyoscyamus niger), Marsh Mallow (Althaea officinalis), Hollyhock Mallow (Malva alcea), Dark Mullein (Verbascum nigrum) and Willowherb (Epilobium angustifolium). ${ }^{9-11}$ 
An almost stand of mainly Black Elder (Sambucus nigra) woodland grows only on the old island core. Stands of Dog Rose (Rosa canina), False Dog Rose (Rosa subcanina), Rugosa Rose (Rosa rugosa), European Dewberry (Rubus caesius) and Common Sea-buckthorn (Hippophae rhamnoides) are spreading across the deposited area of the island, thereby reducing year by year the area of habitat available for ground-breeding birds.

\section{Data collection}

I was responsible for monitoring the Walfisch Island nature reserve as a volunteer bird warden and assistant ringer between 1977 and 2006, and from 2000 as a licensed ringer for the responsible Hidden see ringing center. The Shelduck ringing data recorded during this period were included in relevant publications. ${ }^{7,12,13}$ Artificial nest holes, as already mentioned by Niethammer, ${ }^{14}$ have been provided for the Shelduck on Walfisch Island since about the mid-1970s. The initial artificial nest holes were made of iron or steel pipes some $20 \mathrm{~cm}$ in diameter and about $1 \mathrm{~m}$ in length, and were set at an angle into the ground ending in a buried metal or plastic barrel. A few of these first breeding holes were unattractive for the Shelduck as the iron pipes rusted through and filled up with sand. From 2000, the number of artificial breeding holes was increased to a total of 17 .

Some of these nest holes had a stoneware drainage pipe with a diameter of $20 \mathrm{~cm}$ as entrance. Artificial nests required sand removal, stemming from excavation activities involving Water Voles and sand deposits from weather related conditions. After the breeding season in September, the artificial nest holes were cleaned and the eggs that had not hatched removed. The entrances to some of the artificial nest holes became overgrown annually due to the progressive vegetation succession, especially from Dog Rose, False Dog Rose, Rugosa Rose, European Dewberry, and Common Sea-buckthorn, and had to be cut clear in spring. Without this regular maintenance and cleaning work, the artificial nest holes would have rapidly become unusable for the Shelduck, and the progressive breeding population of Shelduck on Walfisch Island would not have been possible.

Maintenance work on Walfisch Island was carried out with about the same intensity of study days during the two study periods under comparison here 1971-1988 and 1989-2005. The nest site seeking or nest site visiting female Shelduck at the artificial nest holes, or at the dens dug by foxes mainly in winter, were systematically captured using live box traps (as used for cats and martens for example) or by hand from the nest. Shelduck females nesting under the wooden huts or plank piles were also captured using nets or alternatively by hand. In the case of multiple captures of the same bird in the course of a year, only the data from the first capture were evaluated.

\section{Results}

\section{Population development}

Shelducks with their young were previously observed in 1958, 1959 and $1961^{15,16}$ on Walfisch Island. The first breeding record for Walfisch Island - the find of an egg shell - was recorded in 1962. ${ }^{17,18}$ Only individual, to very few breeding pairs, were recorded in the 1970s and 1980s (Figure 2). A progressive Shelduck population development started only at the end of the 1990s, with the creation of artificial breeding holes.

\section{Breeding biology information}

Some $64 \%(n=77)$ of the breeding sites were located in artificial underground nest holes. The relatively high proportion of 15\% (n
$=18$ ) of so-called free breeders (breeding places in vegetation) is remarkable. These birds brooded mainly in dense Common SeaBuckthorn thickets, as well as in very dense stands of Dog Rose in the southern part of the island (Figure 3).

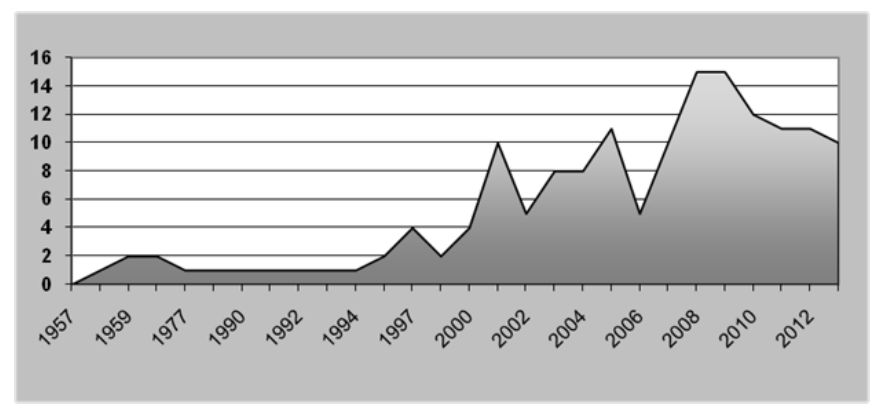

Figure 2 Development of the Shelduck breeding population in the Walfisch Island nature reserve between 1957 and 2013.

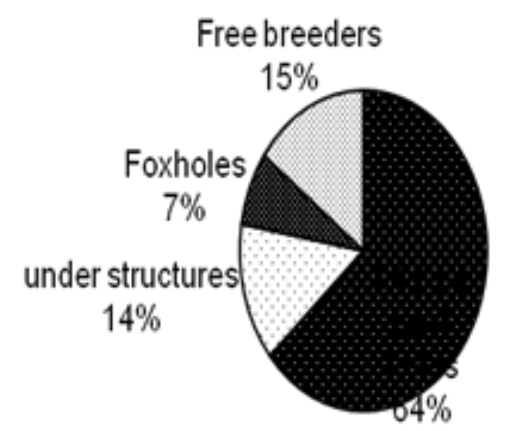

Figure 3 Shelduck breeding sites on Walfisch Island between 1990 and 2010 $(n=121)$.

Some $14 \%(\mathrm{n}=17)$ of Shelduck brooded under the then available wooden huts, which were occupied by the bird warden and his assistants in the breeding season, as well as under planks and woodpiles. Only $7 \%(n=9)$ brooded in dens dug by foxes in winter.

\section{Clutch size}

The average clutch size was 11.11 eggs $(\mathrm{n}=17$ females with 189 eggs).There were two cases of clutches with more than 18 eggs, which were therefore allotted to two females. In one case, both females (Hiddensee EA055842 and Hiddensee EA127148) were observed brooding on the common clutch of 19 eggs:
I. Hiddensee EA127148 on 20.05.2003 on 17 eggs
II. Hiddensee EA127148 on 22.05 .2003 on 19 eggs
III. Hiddensee EA055842 on 22.05.2003 on 19 eggs

\section{Start of egg-laying}

The earliest dates for clutches on Walfisch Island were recorded for the following ringed Shelducks:

I. Hiddensee EA139753 on 11.05.2005 on a clutch with 11 eggs.

II. Hiddensee EA138154 am 14.05.2005 on a clutch with 22 eggs, which can certainly be allotted to at least two females.

The earliest seasonal capture of a female seeking out its breeding site was on 09.05 (2001).

It was not possible to definitely establish if a female captured on 03.04 (1999) was on the way to its (later) breeding site. 
The latest seasonal captures of females visiting a breeding site were on 15.07 (1986) and 17.07 (1986).

\section{Mixed clutches}

A mixed clutch with a Red-breasted Merganser was recorded in a single instance:

i. Hiddensee EA125497 on 27.05.2002 on 7 Shelduck and 4 Red-

Table I Shelduck ringing date and recovery date breasted Merganser eggs. On 07.06.2002, the same Shelduck female brooded on 11 Shelduck and und 4 Red-breasted Merganser eggs.

\section{Breeding site fidelity}

Several recoveries of Shelduck ringed on Walfisch Island, and recaptured there, indicate - in part - long-term breeding site fidelity $(\mathrm{o}=$ ringing date; $\mathrm{v}=$ recovery date): (Table 1$)$.

\begin{tabular}{|c|c|}
\hline Shelduck ringing date & Shelduck recovery date \\
\hline Hiddensee 315084, o I7.06.1972 & v 17.06.1977 after I 826 days (5 years) \\
\hline Hiddensee 315097, o I6.06.1973 & v 04.07. 1976 after II I 4 days( 3 years 18 days) \\
\hline Hiddensee 315098, o 17.06.1973, & $\begin{array}{l}\text { v 26.06. } 1976 \text { after I } 105 \text { days ( } 3 \text { years } 9 \text { days) } \\
\vee 23.05 .1999 \text { after } 1072 \text { days ( } 2 \text { years II months } 8 \text { days) }\end{array}$ \\
\hline Hiddensee EA55832, ○ 15.06.1996 & $\begin{array}{l}\text { v II.05.200I after I79I days (4 years } 10 \text { months } 26 \text { days) thereafter on several occasions until } \\
\text { v } 01.06 .200 \text { I after } 1812 \text { days ( } 4 \text { years II months } 17 \text { days) }\end{array}$ \\
\hline Hiddensee EA55840, ○ 07.06.1997 & 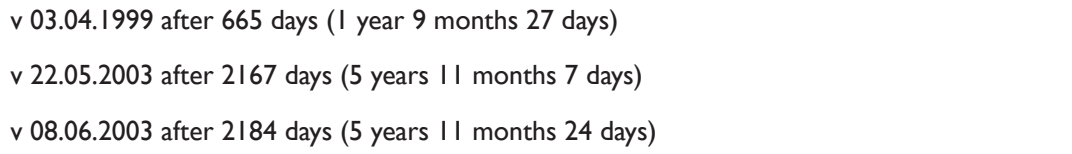 \\
\hline Hiddensee EA055842, ○ I5.06.1997 & $\begin{array}{l}\text { v I6.05.2004 after } 2527 \text { days (6 years II months I Tag) } \\
\text { v 29.05.2004 after } 2540 \text { days ( } 6 \text { years II months I } 3 \text { days) } \\
\text { v 13.06.2005 after } 2920 \text { days ( } 7 \text { years II months } 29 \text { days) }\end{array}$ \\
\hline Hiddensee EA0696I2, o 24.05.2003 & v 23.06.2008 after 1857 days ( 5 years 30 days) \\
\hline Hiddensee EAI38I54, o 20.05.2004, & v 14.05.2005 after 358 days (I I months 25 days) \\
\hline Hiddensee EAI 38233, o 30.06.2004 & $\begin{array}{l}\text { v I I.06.2005 after } 346 \text { days (I I months } 19 \text { days) } \\
\text { v 26.06.2005 after } 36 \text { I days (I I months } 26 \text { days) }\end{array}$ \\
\hline
\end{tabular}

Two Shelduck ringed on the island of Langen werder as chicks were later recovered on Walfisch Island, one of them an individual originally ringed in 1980 and recovered in three breeding seasons (1986, 1987 and 1990). These recoveries indicate settlement behavior by the young birds in the vicinity of their birthplace. ${ }^{19}$

\section{Age}

According to Kolbe, ${ }^{20}$ Shelduck become sexually mature at the end of their second year of life. Hori ${ }^{21}$ states that Shelduck are sexually mature at 22 months. On this basis, Shelduck Hidden see EA055842 (c.f. recovery No. 6) can be assumed to be at least 10 years old.
Shelduck Hidden see EA062365, caught in a net on 24.06.2014 (after 4304 days), was ringed as a first year bird on 11.09.1993 on the island of Langen werder, some $12 \mathrm{~km}$ NNE of Walfisch Island. This bird was aged at almost 12 years.

\section{Migratory behavior}

Of the Shelduck ringed on Walfisch Island, in addition to recoveries within Wismar Bay, there are altogether records of only three other recoveries: one a near recovery (up to $100 \mathrm{~km}$ ) and two older distant recoveries $(>100 \mathrm{~km})$ : (Table 2$)$.

Table 2 One a near recovery (up to $100 \mathrm{~km}$ ) and two older distant recoveries $(>100 \mathrm{~km})$

\begin{tabular}{|c|c|}
\hline Shelduck ringing date & Shelduck recovery date \\
\hline \multirow{2}{*}{ Hiddensee EA037935, ○ I.J. I0.09.199I } & v 31.12.1992 Travemünde, Germany \\
\hline & $37 \mathrm{~km} \mathrm{~W}$ after 478 days (I year 3 months $2 \mid$ days) \\
\hline \multirow{2}{*}{ Hiddensee $356506, \mathrm{o}$ ad. 16.6 .1984} & v 31.3.1987 Pellworm, Germany $\left(54^{\circ} 3 I^{\prime} 00 \mathrm{~N} 008^{\circ} 38^{\prime} 00 \mathrm{E}\right)$ \\
\hline & $193 \mathrm{~km}$ WNW after 1018 days ( 2 years 9 months 15 days) \\
\hline \multirow{3}{*}{ Hiddensee 338560, ○ IJJ. I5.07.1979 } & +30.06.1982 Baie des Veys, Manche, \\
\hline & France $\left(49^{\circ} 19^{\prime} 00 \mathrm{~N} 001^{\circ} 09^{\prime} 00 \mathrm{~W}\right)$ \\
\hline & $1007 \mathrm{~km}$ WSW after 108I days (2 years II months I5 days) \\
\hline
\end{tabular}


Recovery No. 3 represents the mostly westerly record of an East German Shelduck.

\section{Biometrics}

The average measured wing length of 25 females was $313.68 \mathrm{~mm}$.

\section{Forward displacement of the start of breeding}

A comparison of captures of breeding site seeking and breeding site visiting females in the period 1971 to 1988 , with captures in the period 1989 to 2005, show a forward displacement of the start of breeding of 19.16 days. That is the equivalent of an average displacement of 1.28 days annually. The double maximum capture peaks of each evaluated capture period are also remarkable. In this respect breeding site seeking or breeding site visiting Shelduck females are treated as breeding birds (Figure $4 \& 5$ ).

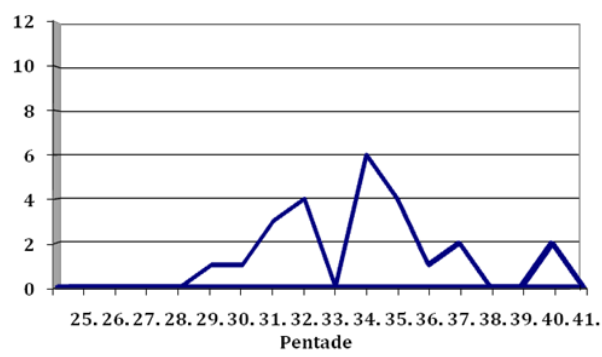

Q1971.1988

Figure 4 Pentade maxima of captured and ringed female Shelduck on Walfisch Island between I97I and $1988(\mathrm{n}=24)$.

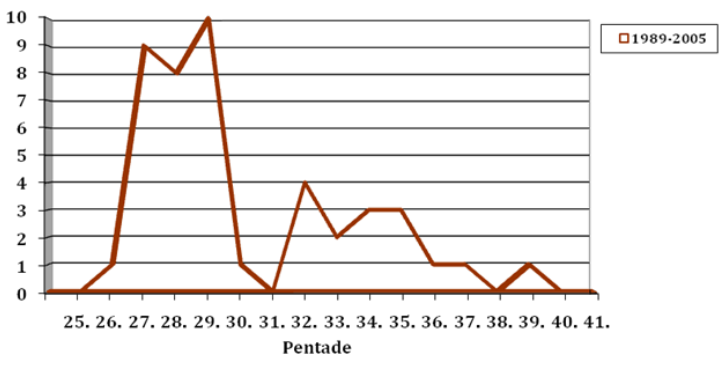

Figure 5 Pentade maxima of captured and ringed female Shelduck on Walfisch Island between 1989 and $2005(n=44)$.

\section{Discussion}

\section{Clutch size}

Full clutches are described by Niethammer ${ }^{15}$ as 7-12 eggs, with occasionally more eggs, and Hoeher ${ }^{22}$ as well as Glutz von Blotzheim ${ }^{23}$ 8-12 eggs. In other areas of the distribution range, the Shelduck lays $10-18$ eggs. ${ }^{24}$

\section{Start of egg-laying}

According to Kolbe, ${ }^{20}$ egg-laying "on our coast" begins in midMay. Glutz von Blotzheim ${ }^{23}$ puts the start of egg-laying at the end of April/beginning of May. According to Nehls in Klafs \& Stübs ${ }^{2}$, the start of egg-laying takes place mostly in the $2^{\text {nd }}$ May pentade, and seldom in the last April pentade or earlier.

\section{Age}

According to the Euring Database ${ }^{24}$ the British Shelduck GM.96505 reached the maximum age of 24 years and 10 months, the Swedish Shelduck 90A00877 an age of $>17$ years and 9 Months. Staav ${ }^{25}$ states that the individual, London GP.44864, reached the maximum age of 18 years and 11 months. The maximum age of an East German ringed bird (in the area of responsibility of Hiddensee ringing center, Germany) is given as 18 years and 8 months $(6,804$ days $) .{ }^{19}$

\section{Forward displacement of the start of breeding}

Climatic data from the Boltenhagen meteorological station, some $15 \mathrm{~km}$ WNW of Walfisch Island, show a marked warming of altogether $+5,62^{\circ} \mathrm{C}$ for the breeding-relevant months of February to June in the period of study 1989-2005, when compared with the period of study 1971-1988. At the same time, a comparison of other climatic data for the two periods shows an increase in the amount of precipitation of $+18.941 / \mathrm{m}^{2}$ and an average increase of 53.90 hours of sunshine. The months selected as breeding-relevant for Shelduck in the breeding area are the months between February (first arrival) and June (departure/ molt migration). ${ }^{26}$

Based on the climatic data presented in (Tables 3-5), climate warming can be assumed to be the cause of the forward displacement of the Shelduck breeding season on Walfisch Island; the increase in the mean monthly temperature of the breeding-relevant months (Table 3) appears to be particularly important in this respect. Forward displacement of the breeding season for birds was previously mentioned by Lack $^{27}$ and Crick et al. ${ }^{28} \mathrm{~A}$ change in predator pressure ${ }^{29}$ on the Shelduck as an explanation for forward breeding season displacement on Walfisch Island is improbable, as the number of Herring Gull (Larus argentatus) pairs, as possible predators, breeding on the island was almost constant during both study periods.

The Red Foxes that reach the island during some winters are mostly hunted in March/April. One consequence of the increase in the mean monthly temperature of the breeding-relevant months could be an earlier availability of food, especially for the young birds. ${ }^{30,31}$ Direct temperature effects can also lead to earlier egg-laying. ${ }^{32,33}$ More detailed studies of this aspect of climate warming for the study area are not available.

Table 3 Mean monthly temperature in ${ }^{\circ} \mathrm{C}$ for the periods of study 197I-1988 and 1989-2005

\begin{tabular}{|c|c|c|c|}
\hline \multicolumn{4}{|c|}{ Mean monthly temperature in ${ }^{\circ} \mathrm{C}$} \\
\hline Month & Period $197 \mid-1988$ & Period 1989-2005 & Difference Between the Periods I97 I-I 988 and $1989-2005$ \\
\hline February & 0.51 & 2.40 & +1.89 \\
\hline March & 3.13 & 4.47 & +1.34 \\
\hline April & 6.29 & 7.48 & +1.19 \\
\hline May & 11.05 & 11.84 & +0.79 \\
\hline June & 14.52 & 14.93 & +0.41 \\
\hline \multicolumn{3}{|c|}{ Difference for the period February-June | $97 \mid$ - 1988} & $+5.62^{\circ} \mathrm{C}$ \\
\hline
\end{tabular}


Table 4 Mean amount of precipitation in liters for the periods of study I97I-I988 and I989-2005

\begin{tabular}{|c|c|c|c|}
\hline \multicolumn{4}{|c|}{ Mean amount of precipitation in liters } \\
\hline Month & Period I97I-1988 & Period $1989-2005$ & Difference Between the Periods I97 I-1988 and 1989-2005 \\
\hline February & 19.04 & 38.14 & +19.1 \\
\hline March & 38.11 & 37.00 & -1.11 \\
\hline April & 33.44 & 34.48 & +1.04 \\
\hline May & 48.33 & 49.71 & +1.38 \\
\hline June & 63.17 & 61.70 & -1.47 \\
\hline \multicolumn{3}{|c|}{ Difference for the period February-June 1971-1988 } & $+|8.94|$ \\
\hline
\end{tabular}

Table 5 Mean number of hours of sunshine for the periods of study 197/-1988 and 1989-2005

\begin{tabular}{|c|c|c|c|}
\hline \multicolumn{4}{|c|}{ Mean number of hours of sunshine } \\
\hline Month & Period I97I-I988 & Period 1989-2005 & Difference between the periods I97 I-I988 and I989-2005 \\
\hline February & 67.24 & 71.92 & 4.68 \\
\hline March & 111.42 & 129.91 & 18.49 \\
\hline April & 175.44 & 185.88 & 10.44 \\
\hline May & 241.95 & 260.54 & 18.59 \\
\hline June & 231.40 & 233.10 & 1.7 \\
\hline \multicolumn{4}{|c|}{ Difference for the period February-June 197I-1988 } \\
\hline
\end{tabular}

For 53 British breeding bird species, Møller et al. ${ }^{34}$ state an average earlier start to egg-laying of 0.13 days per year. Root et al. ${ }^{35}$ come to a higher estimate of 0.37 days per year. A possible forward displacement in the Shelduck breeding season is not mentioned in either publication. According to Møller et al., ${ }^{36}$ 'one-brood-species' displace their breeding season forward on average by 0.44 days per year.

The relationship between local temperatures and arrival in the breeding territory varies depending on the migration route. ${ }^{37}$ The forward displacement of the breeding season is supposed to be greater between resident as opposed to migratory, and short-distance as opposed to long-distance migrants respectively, ${ }^{32}$ as resident and short-distance migrants can react more rapidly to temperature changes than long-distance migrants. A considerable forward displacement of 1.28 days per year in the breeding season of the Shelduck, as shortdistance migrant, is therefore compatible with the study results of ${ }^{32}$ (2001).

For the time frame 1971 to 2008 , Sellin \& Schirmeister ${ }^{24}$ established a significantly earlier arrival date of the Shelduck in Western Pomerania, on the southern Baltic coast in the area of the River Oder estuary, without quantifying the number of days.

\section{Biometrics}

Madge \& Burn (1989), as also Glutz von Blotzheim, ${ }^{21}$ state an average wing length of $303 \mathrm{~mm}(n=7)$.

\section{Acknowledgements}

None.

\section{Conflict of interest}

The author declares no conflict of interest.

\section{References}

1. Klafs G, Stübs J. Die Vogelwelt Mecklenburgs. Jena: Fischer; 1977.

2. Klafs G, Stübs J. Die Vogelwelt Mecklenburgs. Bezirke Rostock, Schwerin, Neubrandenburg. Jena: Fischer; 1987.

3. Strache RR. Brut-und Rastgebiete für Küstenvögel an der Wismarbucht: Bestandsentwicklung, Gefährdungsursachen, Schutzmaßnahmen. Seevögel. Zeitschrift Verein Jordsand 19, Sonderheft; 1998. p. 41-45.

4. Kuhk R. Die Vögel Mecklenburgs. Germany, Europe; 1939.

5. Eichstädt WW, Scheller D, Sellin W, et al. Atlas der Brutvögel in Mecklenburg-Vorpommern. Europe: Steffen Verlag; 2006.

6. Köppen U. Küstenvogelschutz in Mecklenburg-Vorpommern heuteOrganisation, Probleme und Konzepte. Seevögel. Zeitschrift Verein Jordsand 19, Sonderheft; 1998. p. 31-40.

7. Köppen U, Graumann G. Brutbestände der Küstenvögel in Schutzgebieten Mecklenburg-Vorpommerns 1993, 1994 und 1996. Seevögel, Zeitschrift Verein Jordsand. 1998;19(1):11-16.

8. Flade M. Die Brutvogelgemeinschaften Mittel und Norddeutschlands. Journal fur Ornithologie. 1994;136(1):89-99.

9. Schreiber E. Die Vegetation der Insel Walfisch im Jahr ADERHOLM Mitteilungsblatt der Freunde der Insel Walfisch. Nr. 2006;5:1-10.

10. Henker H, Sluschny H. Die Vegetation der Insel Walfisch. Naturschutzarbeit in Meckl. 1977;20(1-2):35-40. 
11. Pankow H, Mahnke W. Die Vegetation der Insel Walfisch. Arch Nat Meckl IX. 1963:135-149.

12. Siefke A. Brutbestände der Küstenvögel 1989-1992 in den Schutzgebieten Mecklenburg-Vorpommerns. Seevögel, Zeitschrift Verein Jordsand. 1993;14(3):37-41.

13. Köppen U, Graumann G. Brutbestände der Küstenvögel in Schutzgebieten Mecklenburg-Vorpommerns 1997. Seevögel, Zeitschrift Verein Jordsand. 1999;20(2):49-51.

14. Köppen U. Brutbestände der Küstenvögel in Schutzgebieten Mecklenburg- Vorpommerns in den Jahren 1999 und 2000. Seevögel, Zeitschrift Verein Jordsand. 2001;22(4):104-105.

15. Dankert C. Schutz den Brutvögeln auf der Insel Walfisch. Naturschutzarbeit in Mecklenburg. 1961;4(1):15-18.

16. Johansen H. Die Vogelfauna Westsibiriens. J Orn. 1959;100(3):313-336

17. Niethammer G. Handbuch der deutschen Vogelkunde Band 2. Germany: Akademische Verlagsgesellschaft mbH; 1938.

18. Mahnke W, Dankert C. Die Entwicklung der Insel Walfisch zur Seevogelbrutstätte. Falke. 1963;10:147-152.

19. Heinicke T, Köppen U. Vogelzug in Ostdeutschland I-Wasservögel Teil 1. In: Berichte D, editor. Vogelwarte Hiddensee Artikel Nr. 2007. p. $138-144$.

20. Kolbe H. Die Entenvögel der Welt. Radebeul, Germany; 1972.

21. Hori J. The breeding biology of the Shelduck Tadorna Tadorna. Ibis 1964;106(3):333-360.

22. Hoeher S. Gelege der Vögel Mitteleuropas und einiger in nördlicheren und südlicheren Breiten brütender Arten. Radebeul, Germany; 1973.

23. Glutz von Blotzheim UN. Handbuch der Vögel Mitteleuropas. Bd 2 Anseriformes (Teil 1) 2 durchgeseh, Auflage. Germany; 1990.

24. http://www.euring.org/data_and_codes/longevity-voous.htm

25. http://www.vogeltrekstation.nl/resultaten/longevity-list-roland-staav
26. Sellin D, Schirmeister B. Die Brandgans Tadorna tadorna im Naturschutzgebiet Peenemünder Haken, Struck und Ruden. Orn Rundbrief Meckl Vorp Band. 2009;46(2):157-166.

27. Lack D. Population Studies of Birds. India: Oxford University Press; 1966. p. 469-471.

28. Crick HQP, Dudley C, Glue DE, et al. UK birds are laying eggs earlier. Nature. 1997;388:526.

29. Drever MC, Clark RG. Spring temperature, clutch intiation date and duck nest success: a test of the mismatch hypothesis. J Anim Ecol. 2007;76:139-148.

30. Alerstram T, Högstedt G. Bird migration and reproduction in relation to habitats for survival and breeding. Ornis Scandinavica. 1982;13(1):2537 .

31. Carey C. The impacts of climate change on the annual cycles of birds. Philosophical Transactions of the royal society. 2009;364(1534):33213330.

32. Silverin B, Wingfield J, Stokkan K, et al. Ambient temperature effects on photo induced gonadal cycles and hormonal secretion patterns in great tits from three different breeding latitudes. Horm Behav. 2008;54(1):60 68

33. Visser ME, Holleman LJM, Caro SP. Temperature has a causal effect on avian timing of reproduction. Proc Biol Sci. 2009;35(1665):89-110.

34. Møller AP, Fiedler W, Berthold P. Effects of Climate Change on Birds. Oxford University Press; 2010. 336 p.

35. Root TR, Price JT, Hall KR. Fingerprints of global warming on wild animals and plants. Nature. 2003;421:57-60.

36. Møller APE, Flensted JE, Klarborg K, et al. Climate change affects the duration of the reproductive season in birds. J Anim Ecol. 2010;79(4):777-784

37. Pearce-Higgins JW, Green RE. Birds and climate change. Impacts and Conservation Responses. England: Cambridge University Press; 2014. 